\title{
JUDGE MAGRUDER AND THE LABOR CONTRACT
}

\author{
Harry H. Wellington*
}

$I^{1}$

$\mathrm{T}$ is a commonplace among former law clerks of "the Judge" who have gone on to a Supreme Court clerkship - gone, as Learned Hand might have it, from "puisne judge" to "puisne justice" - to remark, when the talk turns to the judicial process, that its nature is nowhere more agreeable than on the Court of Appeals for the First Circuit. In part, this assessment may reflect a sentimental attachment to one's first job. In part, however, it reflects the tempo and the mood of that unique court in downtown Boston.

It is a small court, three men, with not a great amount of business; and with business that receives not a great amount of publicity. One has a feeling that there is time to watch from the chambers of the Chief Judge the occasional ship in the Boston harbor, or the red and white lights at dusk escaping the crowded city.

In this environment, a judge's professional life can resemble in one very important respect the life of a law professor at an understanding university. Here also there is time for consideration and for reflection. Most judges, because their courts do have a great amount of business, are short on this asset. Calvert Magruder not only has it, but also has the ability, the training, and the disposition to exploit it. So he has done and nobly. The record - the Federal Reporter for the past twenty years - discloses this as a matter of law.

No article, or law-review issue of appreciation, is a substitute for his opinions. Like every record, his must be read. But something of Judge Magruder's performance can be told, and perhaps with profit. No doubt the telling would be especially valuable if it described some aspect of his conception of a judge's responsibility to Congress and to the Supreme Court. This is not a theme

* Associate Professor of Law, Yale Law School. A.B., U. of Pa., I947; LL.B., Harvard, I952. I am indebted to Stephen H. Sachs, a member of the second-year class of the Yale Law School, for assistance on a portion of this article. 
treated openly, grandly, or epigrammatically, in Magruder's opinions. Yet the Judge has come back again and again upon these questions of responsibility. The result is subtly woven into the fabric of decision.

It is not my purpose here to try to unravel enough of these decisions to permit me to generalize about the Judge's conclusions. I shall try, however, to look at Judge Magruder's view of his responsibility to Court and Congress as it reveals itself in several decisions on a single statutory provision, one which has given rise to many of today's most difficult labor-law problems.

These past few years Magruder has toiled at length with the matters to which I would turn. They are perplexing, and yet they revolve around this seemingly simple statutory language:

Suits for violation of contracts between an employer and a labor organization ... may be brought in any district court of the United States having jurisdiction of the parties, without respect to the amount in controversy or without regard to the citizenship of the parties.

Of course, the provision, section 30 of the Taft-Hartley Act, ${ }^{1}$ is not simple at all. If it were, the Judge would not now have better than a dozen opinions on one or more of the problems created by the section. Three of these problems - fortunately three of the more important - are best suited to my purpose. One is a constitutional problem; a second concerns the accommodation of the Norris-LaGuardia Act to section 30r; and the third has to do with the role of a judge in a pre-arbitration proceeding under this statute.

\section{Section zot ANd the Constitution}

To make ready for Magruder, some background is necessary., In the beginning is the question of which law, state or federal, determines the substantive issues at stake in an action brought under section zor. Federal law, was the conclusion of the Supreme Court in June 1957. This was Lincoln Mills. ${ }^{2}$ Earlier, in March 1955, the Court in Westinghouse ${ }^{3}$ had been unable to resolve

\footnotetext{
${ }^{1}$ 6r Stat. 156 (I947), 29 U.S.C. § I85 (I952).

2 Textile Workers v. Lincoln Mills, 353 U.S. 448 (I957).

${ }^{3}$ Association of Westinghouse Salaried Employees v. Westinghouse Elec. Corp., 348 U.S. 437 (I955).
} 
the question. Two Justices thought that substantive issues were governed by federal law. ${ }^{4}$ A third Justice seemed to agree. ${ }^{5}$ Three other members of the Court committed themselves to the view that state law regulated these issues. ${ }^{6}$ The position of the remaining three went unrecorded; ${ }^{7}$ and the yield was no majority opinion.

This determination of the applicable law is intertwined, although not inexorably so, with the constitutionality of section 301 . If federal law regulates substantive rights, section $30 \mathrm{r}$ is plainly constitutional. ${ }^{8}$ If state law applies, the section's constitutionality would be in doubt. In a case "arising under the laws of the United States," substantive issues ordinarily are governed by federal law. ${ }^{9}$ If there is no substantive federal law in issue, under what law of the United States does the case arise?

To avoid this constitutional riddle, Mr. Justice Frankfurter in Westinghouse, speaking for himself and those colleagues avowedly unable to read the language of section $30 \mathrm{I}$ as creating a new code of federal contract law, gave the statute a restrictive construction. Since two other Justices joined in this result, the case was disposed of. ${ }^{10}$ The Court held that section $30 \mathrm{I}$ was not meant to apply to

${ }^{4} I d$. at ${ }_{465}^{6}$ (Douglas and Black, JJ., dissenting).

${ }^{5} I d$. at $46 \mathrm{I}$ (Reed, J., concurring).

${ }^{B}$ Id. at 439 (opinion of Frankfurter, J., joined by Burton and Minton, JJ.).

${ }^{7} I d$. at $46 \mathrm{I}$. Mr. Justice Harlan did not participate. The Chief Justice, joined by Mr. Justice Clark, did not remark upon the question.

${ }^{8}$ There is no constitutional difficulty. Article III, $\S 2$, extends the judicial power to cases "arising under ... the Laws of the United States . ..." The power of Congress to regulate these labor-management controversies under the Commerce Clause is plain. . . . A case or controversy arising under $\$ 301$ (a) is, therefore, one within the purview of judicial power as defined in Article III. Textile Workers v. Lincoln Mills, 353 U.S. 448, 457 (1957).

${ }^{9}$ Almost without exception, decisions under the general statutory grants of jurisdiction strikingly similar to the constitutional wording, have tested jurisdiction in terms of the presence, as an integral part of plaintiff's cause of action, of an issue calling for interpretation or application of federal law....

Association of Westinghouse Salaried Employees v. Westinghouse Elec. Corp., 348 U.S. 437, 450 (r955) (opinion of Frankfurter, J.).

${ }^{10}$ Perhaps, to avoid a constitutional question a court may construe a statute after the fashion of the Supreme Court in Westinghouse. Absent the existence of a constitutional question, or some other large principle, see Bickel \& Wellington, Legislative Purpose and the Judicial Process: The Lincoln Mills Case, 7I HaRv. L. REv. I (I957), such a construction seems hard to square with the English language.

The only question we see here is one of statutory interpretation. For us the language of $\S 301$ is not sufficiently explicit nor its legislative history sufficiently clear to indicate that Congress intended to authorize a union to enforce in a federal court the uniquely personal right of an employee for whom it had bargained to receive compensation for services rendered his employer. Thus 
suits for damages based upon the "uniquely personal rights" of employees. ${ }^{11}$ Since the plaintiff union in Westinghouse was suing for some of its members' back wages, this construction put it out of court. And the holding of the case left federal judges without guidance in damage actions not involving "uniquely personal" employee rights. The judges were to remain in this unhappy state until Lincoln Mills.

The second Mead case ${ }^{12}$ — just such a damage action - came before Judge Magruder's court one year after Westinghouse, and one year before Lincoln Mills. The facts are simple. When the Mead Co. "grounded" a truck driver, the Teamsters immediately struck, and closed the plant down for twelve weeks. The company's theory was that in striking over this issue the Teamsters had broken an implied provision in the contract. A suit for damages by an employer against the union for an alleged breach of an alleged "no-strike" clause is plainly cognizable under section $30 x$. And so at least some of the issues the Supreme Court had successfully sidestepped in Westinghouse had to be met by Judge Magruder in Mead II.

From a reading of his opinion in the case two facts are clear: (I) The Judge thought that the result on the merits would be the same under federal or state law; ${ }^{13}$ and (2) he thought that on the merits the plaintiff should win. What was also clear at the time of Mead II was that no matter what the court of appeals did, the issues left unresolved by Westinghouse would eventually have to be decided by the Supreme Court. Indeed, at the time

viewed, it becomes unnecessary for us either to make labor policy or to raise constitutional issues.

Association of Westinghouse Salaried Employees v. Westinghouse Elec. Corp., 348 U.S. 437, 46I (r955) (opinion of Warren, C.J., joined by Clark, J.). Yet the Chief Justice and Mr. Justice Clark joined the majority opinion in Lincoln Mills.

${ }^{12}$ Id. at 460. Lincoln Mills eliminated any constitutional difficulty, and I should think it would now be quite proper, in an appropriate case, for the Court to re-examine Westinghouse's construction of $\S 301$. Absent constitutional problems, the statute seems plainly to apply to the facts in Westinghouse. See note to supra.

${ }^{12}$ International Bhd. of Teamsters v. W. L. Mead, Inc., 230 F.2d 576 (Ist Cir.), cert. dismissed, $35^{2}$ U.S. 802 (I956). The first Mead case, W. L. Mead, Inc. v. International Bhd. of Teamsters, $2 I_{7}$ F.2d 6 (Ist Cir. I954), was an injunction proceeding. See pp. $1277-78$ infra.

${ }^{13}$ Accordingly, since Judge Magruder held the statute constitutional on either reading, there was no need for him to commit himself upon the issue of the applicable law, an issue which had been fully explored by the Supreme Court. 
it looked like this would occur in Mead II itself. Section 301 was too important to be long ignored.

In this situation Magruder's principal responsibility to the Supreme Court was clear. His was the job of instructing the Justices. A good opinion below on a difficult question of law is probably the most helpful document the Supreme Court can have on certiorari or appeal. Unlike a brief, it is the product of a disinterested lawyer. Unlike a law-review article, it deals with the particular problem facing the Court.

To the several Justices of the Supreme Court who had committed themselves to the view that substantive rights in a section 301 action were governed by state law, and to those Justices who had not committed themselves upon this question, Magruder could be most helpful by attempting to resolve the constitutional doubts which had troubled Mr. Justice Frankfurter in Westinghouse.

To what extent may Congress under the provision of article III, which extends the judicial power to "all cases, in Law and Equity, arising under ... the laws of the United States," confer jurisdiction upon the federal courts without at the same time legislating substantive rights? No one would suggest that under this provision of article III Congress may grant to the courts jurisdiction over subject matter which it cannot reach substantively under article I. Perhaps, however, it has the power to go just as far jurisdictionally as it could have gone substantively. The national interest in a particular area of law susceptible to regulation under article I may not demand complete and immediate substantive uniformity. Room for experimentation, particularly if the area of law is just emerging, can be useful. Yet, a tendency towards ultimate uniformity may be a present need. A federal forum can satisfy this need even though state law governs substantive rights. Federal judges are likely to approach unresolved questions of state law from a unifying national perspective. Decisions of the federal courts are bound to influence state courts particularly when the problems could be regulated, although they are not yet regulated, at the national level. ${ }^{14}$

Less extreme perhaps, although shading into this position, is what sometimes is described as "protective jurisdiction." ${ }^{15}$ In

${ }^{14}$ See Bickel \& Wellington, Legislative Purpose and the Judicial Process: The Lincoln Mills Case, 7I HARv. L. REv. I, I9-22 (I957).

${ }^{15}$ See Textile Workers v. American Thread Co., I13 F. Supp. 137 (D. Mass. 
order to protect an existing federal substantive policy, Congress may confer jurisdiction on a federal court and allow state law, if it thinks state law is adequate, to govern the underlying rights of the litigants. Congress should be able to protect a federally chartered corporation by giving access to a federal forum irrespective of the source of substantive law. ${ }^{16}$ Congress should be able to protect citizens of the District of Columbia in the same fashion. ${ }^{17}$ Similarly, it should be able to open the federal courts to a trustee in bankruptcy although the immediate question involves only state law, if a federal forum is thought to be necessary for the protection of the federal program embodied in the Bankruptcy Act. $^{18}$

The Judge resisted the temptation to "probe the outer limits" 19 of article III jurisdiction, devoting himself instead to the narrow constitutional question present if state law survives under section 30r. He showed how likely it is that federal law would be involved even upon the assumption that state law survives, and therefore, how closely related to conventional jurisdiction the section really is. ${ }^{20}$ The questions whether the union is the bargaining representative, whether a term of the contract is legal, and whether, indeed, the contract is still in force, are all potential issues in a suit for breach of a labor contract. All are issues which may have to be resolved by substantive federal law contained in the National Labor Relations Act. ${ }^{21}$ Indeed, in Mead II itself, Magruder was able to look to the act and its interpretation

I953); Hart \& Wechsler, The Federal Courts and the Federal System 733-47 (r953); Wechsler, Federal Jurisdiction and the Revision of the Judicial Code, I3 Law \& Contemp. Prob. 216, 224-25 (1948); Mishkin, The Federal "Question" in the District Courts, 53 CoLUM. L. REv. 157, I84-96 (r953); Wollett \& Wellington, Federalism and Breach of the Labor Agreement, 7 Stan. L. REv. $445,476-79$ (I955).

${ }^{16}$ See Osborn v. Bank of the United States, 22 U.S. (9 Wheat.) 738 (1824).

${ }^{17}$ See National Mut. Ins. Co. v. Tidewater Transfer Co., 337 U.S. 582 (I949).

${ }^{18}$ See Williams v. Austrian, 33I U.S. 642 (I947); Schumacher v. Beeler, 293 U.S. 367 (I934).

${ }^{10} 230$ F.2d at 58 I.

${ }^{20} 1$ bid.

21 Ibid.

Section 8 enumerates unfair labor practices; these may in some instances become relevant to the validity or interpretation of a collective agreement ..... And a limited number of substantive rights conferred under the Act may incidentally involve the interpretation of the collective agreement. (E.g., $\S 9(\mathrm{a})$.)

Association of Westinghouse Salaried Employees v. Westinghouse Elec. Corp., 348 U.S. 437,443 n.2 (I955) (opinion of Frankfurter, J.). 
by the NLRB for guidance. ${ }^{22}$ The Board in an earlier proceeding had determined that the strike was a breach of contract. ${ }^{23}$

The Mead II opinion by taking the tack it does succeeds to my mind in exposing the limited nature of the constitutional issue raised in the Westinghouse case and in putting it to rest. By avoiding the temptation to explore all the questions suggested by section 30I, Magruder successfully avoided confusion, brought the problem down to scale, and formed an issue that could be decided and dispatched.

Mead II did resolve the constitutional doubts of two of the three members of the Court who faced a constitutional issue in Lincoln Mills. ${ }^{24}$ The majority was unconcerned since it held that Congress intended substantive issues to be decided by judge-made federal law. ${ }^{25}$ But impact is not the test of performance. Magruder, by deciding as little as he could in Mead II, did as much as could be done by a judge on a circuit court.

\section{Section zor and the Norris-LaGuardia Act}

Mead II, of course, proved not to be the vehicle for the Supreme Court's second excursion into the morass of section 301 . Rather this was to be the fate of two subsequent cases decided by the Judge, Goodall-Sanford ${ }^{26}$ and Local $205,{ }^{27}$ and a case from the Fifth Circuit, Lincoln Mills itself.

\footnotetext{
${ }^{22} 230$ F.2d at 584 .

${ }^{23}$ W. L. Mead, Inc., II3 N.L.R.B. I040 (I955). The Mead Company had discharged some employees because they engaged in the strike. This would have been an employer unfair labor practice if the strike had been a protected activity under $\S 7$ of the NLRA, 6I Stat. 140 (I947), 29 U.S.C. § I57 (I952). The Board held it was not protected because the strike was in breach of the collective-bargaining agreement. Cf. NLRB v. Sands Mfg. Co., 306 U.S. 332 (I939).

${ }^{24}$ I do not subscribe to the conclusion of the Court that the substantive law to be applied in a suit under $\S 30 \mathrm{I}$ is federal law. At the same time, I agree with Judge Magruder in International Brotherhood v. W. L. Mead, Inc., 230 F.2d 576 , that some federal rights may necessarily be involved in a $\$ 30 x$ case, and hence that the constitutionality of $\S 3$ or can be upheld as a congressional grant to Federal District Courts of what has been called "protective jurisdiction."

Textile Workers v. Lincoln Mills, 353 U.S. 448,460 (I957) (Burton, J., concurring). Mr. Justice Frankfurter concluded that the statute was unconstitutional. Id. at 484 .

${ }^{25} 353$ U.S. at $456-57$.

${ }^{28}$ Goodall-Sanford, Inc. v. United Textile Workers, 233 F.2d I04 (Ist Cir. I956), aff'd, 353 U.S. 550 (I957).

${ }^{27}$ Local 205, United Elec. Workers v. General Elec. Co., 233 F.2d 85 (Ist Cir. I956), aff'd, 353 U.S. 547 (I957).
} 
Local 205 is Magruder's principal section 301 opinion. This document together with the Judge's opinion in the first Mead case $^{28}$ - a suit by an employer to enjoin a strike prohibited by a collective agreement - is a detailed study of the interrelationship of section $30 \mathrm{I}$ and the Norris-LaGuardia Act. ${ }^{29}$ This interrelationship is another problem which at the time seemed likely to require eventual resolution by the Supreme Court. Part of the problem has been resolved. The remainder surely will come before the Justices soon.

The segment the Court has decided, the easier portion of the total problem, is whether the Norris-LaGuardia Act prevents a district court from ordering specific performance of an arbitration promise in a labor contract. The answer given in Lincoln Mills is no. This is the best part of that opinion, perhaps because it is the only part in which an attempt is made to support a conclusion with reasons. The attempt is most successful where its debt to Judge Magruder's opinion in Local 205 is most apparent. ${ }^{30}$

Local 205 itself was a suit initiated by the union in the federal district court under section 301 to compel the employer to submit two unresolved grievances to arbitration in accordance with a provision of the collective contract. The suit, in other words, was for specific performance of the promise to arbitrate. The district judge dismissed the complaint for want of jurisdiction, resting his decision on the Norris-LaGuardia Act. ${ }^{31}$ This jurisdictional question was at the threshold on appeal to Judge Magruder's court.

The key sections of the Norris-LaGuardia Act are 4, 7, and ${ }_{3}$ (c). Section $4^{32}$ is a blanket prohibition of the issuance by a federal court of an injunction restraining certain enumerated conduct "in any case involving or growing out of any labor dispute." The enumeration is lengthy and it covers a wide variety of peaceful activity - strikes, picketing, etc. - but none of the enumerated activities has any relation whatever to arbitration.

Section $7^{33}$ in terms applies to any other conduct growing out

\footnotetext{
${ }^{28}$ W. L. Mead, Inc. v. International Bhd. of Teamsters, 2 I7 F.2d 6 (Ist Cir. I954).

${ }^{29} 47$ Stat. 70 (I932), as amended, 29 U.S.C. $\$ \S$ roI-15 (1952).

${ }^{30}$ Textile Workers v. Lincoln Mills, 353 U.S. 448, 457-59 (1957).

${ }^{31}$ Local 205, United Elec. Workers v. General Elec. Co., I29 F. Supp. 665 (D. Mass. I955), rev'd, 233 F.2d 85 (Ist Cir. I956), aff'd, 353 U.S. 547 (I957).

${ }^{32} 47$ Stat. 70 (I932), as amended, 29 U.S.C. \& 104 ( $\left.195^{2}\right)$ ).

${ }^{33} 47$ Stat. 7 I (1932), as amended, 29 U.S.C. \& 107 (1952).
} 
of a labor dispute, and requires a federal court to follow certain procedures and to find certain facts before it is empowered to issue "a temporary or permanent injunction." The procedures are calculated to restrict injunctions to cases involving violent or destructive acts. The facts which must be found are that "unlawful acts have been threatened and will be committed unless restrained," that there will be "substantial and irreparable injury to property," that more injury will result from not granting the relief than from granting it, that there is not an adequate remedy at law, and that "the public officers charged with the duty to protect complainant's property are unable or unwilling to furnish adequate protection."

Section $\mathrm{r}_{3}$ (c) ${ }^{34}$ defines "labor dispute" to include "any controversy concerning terms or conditions of employment or concerning the association or representation of persons in negotiating, fixing, maintaining, changing or seeking to arrange terms or conditions of employment ...."

Section I3 (c) itself makes no distinction between labor disputes which can and those which cannot be resolved in litigation by reference to a collective agreement. Judge Magruder had no inclination to read this distinction into the statute. Hence, he had before him in Local 205 a "labor dispute." If an order for specific performance constitutes "a temporary or permanent injunction" within the meaning of section 7 of the Norris-LaGuardia Act, the court of appeals would have had to sustain the district court, for it was not possible to make the findings required by the section. Indeed, one would be hard put to think up a case in which the requirements prerequisite to equitable relief under section 7 could be met in a suit by a union for specific enforcement of a promise to arbitrate.

While for most purposes, therefore, it may be inexcusable conceptualism to suggest that a suit for specific performance is not a suit for an injunction, ${ }^{35}$ here it would seem to be inexcusable literalness to suggest that the relief requested by the union was

\footnotetext{
${ }^{34} 47$ Stat. 73 (I932), as amended, 29 U.S.C. $\$$ II3 (c) ( $\left.195^{2}\right)$.

${ }^{35}$ Of course, the label used to describe the judicial command is not controlling. We would not rest by saying that an order to arbitrate is a "decree for specific performance" in contradistinction to a "mandatory injunction," for each term has been attached so frequently to this type of relief that neither can be rejected out of hand as an inappropriate characterization of it.

Local 205, United Elec. Workers v. General Elec. Co., 233 F.2d 85, 9I (Ist Cir. (1956), aff'd, 353 U.S. 547 (I957).
} 
the type of injunction made difficult to obtain by section 7. Judge Magruder was neither conceptual nor literal. He found that section 7 did not apply, and his opinion carefully documents this conclusion. He drew strength for his conclusion from the fact that the Norris-LaGuardia Act not only exhibits no hostility to arbitration, but indeed encourages it, as it does collective bargaining generally, ${ }^{36}$ and from the fact that the Supreme Court had found the act inapplicable in other labor situations, not involving a strike, in which district courts had been called upon to grant equitable relief. ${ }^{37}$

Judge Magruder's treatment of Norris-LaGuardia and arbitration under section $30 \mathrm{r}$ is, it seems to me, as exactly right in its way as is his constitutional decision in Mead II. It was foreseeable that both problems ultimately would have to be decided by the Supreme Court. And the court of appeals with respect to both problems had the responsibility to point the way to decision. The Norris-LaGuardia problem was easier for a judge to handle because it called for no self-restraint. A full-dress treatment was in order, and this is what Judge Magruder gave his brethren in Washington. In this instance his efforts were rewarded by an opinion which embodied much of his reasoning.

Whether the Judge has done as well by the Justices on the rest of the Norris-LaGuardia-3or problem is more difficult to answer. The issue is this: In a suit under section 301 , does section 4 of the Norris-LaGuardia Act preclude a federal district court from enjoining a peaceful strike in breach of a labor contract? In Mead $I,{ }^{38}$ Magruder held that it did. Mead $I$ is an early case, decided before Westinghouse and Lincoln Mills, and before Brotherhood of R.R. Trainmen v. Chicago River \& Ind. R.R., ${ }^{39}$ a Supreme Court decision allowing a district court to enjoin a peaceful strike over terms and conditions of employment.

The contract-breaking peaceful strike in Mead $I$ grew out of a disagreement over a truck driver's working hours. This plainly would have been a "labor dispute" under section I3(c),

\footnotetext{
${ }^{36} 233$ F.2d at 92 .

${ }^{37}$ See Syres v. Oil Workers, $35^{\circ}$ U.S. 892, reversing per curiam 223 F.2d 739 (5th Cir. I955); Graham v. Brotherhood of Locomotive Firemen, 338 U.S. 232 (I949); Virginian Ry. v. System Fed'n 40, Ry. Employees, 300 U.S. 515 (I937).

${ }^{38}$ W. L. Mead, Inc. v. International Bhd. of Teamsters, $2 I 7$ F.2d 6 (Ist Cir. I954).

${ }^{30} 353$ U.S. 30 (r957).
} 
and accordingly section 4 would have barred an injunction against the strike prior to the passage in 1947 of section 3 or.$^{40}$ The question then is whether in opening the federal courts to actions for breach of contract, and perhaps even providing a federal contract code to govern these actions, Congress was enunciating a policy so strongly in favor of contract enforcement as to make inconsistent the application of Norris-LaGuardia. Put another way, did section 301 repeal by implication - there is clearly no express repeal - the Norris-LaGuardia Act in so far as that statute applies to strikes prohibited by agreement?

The Mead I opinion demonstrates that when Congress enacted the Taft-Hartley Act it had not forgotten about the Norris-LaGuardia Act. To the contrary, it took pains expressly to make its strictures inapplicable in two specific cases: national-emergency strikes, when suit is brought by the Attorney General, and unfair-labor-practice cases, when injunctive relief in a district court is sought by the NLRB. ${ }^{41}$ It requires a good deal of sophistication to find a further repeal, this time by implication, of the anti-injunction statute. ${ }^{42}$

At the time of Mead $I$ it was clear that section 301 represented a congressional policy which favored bilateral enforcement in the courts of collective-bargaining agreements. But the dimensions of the policy were not at all clear. It may well have been supposed that $30 \mathrm{I}$ was merely a cautious beginning, an experiment in bringing the federal courts back, just a bit, into a field where in the past they had performed without distinction. If congressional policy were this tentative, the survival of the Norris-LaGuardia Act's prohibition upon restraining a strike in breach of a labor contract would not be incongruous. It would have been difficult, therefore, to disagree with Judge Magruder's conclusion:

Whatever may be the force of the argument that when an employer has accepted in good faith the procedures of the National Labor Relations Act, as amended, and has made a collective

40 2I7 F.2d at 8; Note, 37 VA. L. REv. 739, 746 (I95I).

${ }^{41} 6$ I Stat. I55 (I947), 29 U.S.C. \& I78(a) (I952) (national-emergency strike); 6I Stat. 149 (I947), 29 U.S.C. \& 160 (h) (I952) (unfair labor practice); see 2I7 F.2d at 9 .

${ }^{42}$ It should be noted again that Judge Magruder in the Local 205 case did not find a repeal of the Norris-LaGuardia Act by implication. Rather, he found that the statute itself, without reference to $\S 30 x$, did not apply to a suit for specific performance of the promise to arbitrate. 
bargaining contract with the duly certified representative of his employees, the employer ought then to be able to obtain an injunction against a strike or picketing which constitutes a violation of the collective agreement, this is a consideration of policy properly to be addressed to the Congress, not to the courts. ${ }^{43}$

But the majority in Lincoln Mills found much more than a tentative congressional policy. Quite the contrary, we now know that the Congress which enacted section $30 \mathrm{r}$ was powerfully committed to the notion that the federal courts belong in this area of labor relations. The courts are to make federal substantive law concerning the collective agreement. They are to develop an arbitration act. There is no suggestion of hesitancy here. There is no suggestion that the courts are merely to experiment a bit.

After Lincoln Mills the Norris-LaGuardia prohibition is incongruous. In the Chicago River \& Indiana R.R. case, ${ }^{44}$ mentioned earlier, a similar incongruity between Norris-LaGuardia and the Railway Labor Act was resolved by the Court's holding unanimously that the anti-injunction statute did not apply. The railroad therefore was successful in obtaining an injunction against a strike over a contract dispute which it had submitted, in accordance with the Railway Labor Act, to the National Railroad Adjustment Board. The Court in this case recognized "the need to accommodate two statutes, when both were adopted as a part of a pattern of labor legislation." 45 Of course, one of the statutes in the case was the Railway Labor Act, which does not, in other situations, explicitly limit the Norris-LaGuardia Act as does TaftHartley. The Court was at pains to limit its decision to an interpretation of the Railway Labor Act. ${ }^{46}$

But there is a potential danger Judge Magruder did not talk about in Mead I (obviously because at the time there was no need to do so), which attends any judicial chipping away at the anti-injunction statute. If a court without clear congressional

\footnotetext{
432 I7 F.2d at Io.

${ }^{44}$ Brotherhood of R.R. Trainmen v. Chicago River \& Ind. R.R., 353 U.S. 30 (1957).

45353 U.S. at 42 .

46 The relationship of labor and management in the railroad industry has developed on a pattern different from other industries. The fundamental premises and principles of the Railway Labor Act are not the same as those which form the basis of the National Labor Relations Act .... It is one of those differences which underlies the controversy in this case.

353 U.S. at 3 I-32 n.2.
} 
direction can say that a strike in breach of contract is not a "labor dispute" under the Norris-LaGuardia Act because it is contrary to the policy of section 30I, why cannot a court also say, for example, that an intermittent work stoppage is not a "labor dispute" because it is an unprotected activity under section 7 of the National Labor Relations Act, and contrary to the policy of that section? ${ }^{47}$

Of course, there is a difference. Lincoln Mills teaches that Congress is committed to active judicial intervention in the area of contract breach. This does not mean that there is a like commitment in other areas of labor relations. But there is no line between contract and no contract, only a large uncertain area. It seems possible that an anxious court might go so far as to suggest that an intermittent work stoppage is a breach of an implied promise in the contract. The parties, such a court might reason, certainly must have agreed not to act contrary to the policies of the NLRA. ${ }^{48}$

History counsels caution. Once courts start to narrow the scope of an anti-injunction statute, the practice becomes difficult to contain, as state experiences show. ${ }^{49}$ And this is dangerous. The injunction in labor disputes is no small weapon; it is a large, powerful persuader. ${ }^{50}$ The Judge was right in suggesting that the

\footnotetext{
${ }^{47}$ National Labor Relations Act § 7, 6I Stat. I40 (I947), 29 U.S.C. § 157 (1952), provides:

Employees shall have the right to self-organization, to form, join or assist Iabor organizations, to bargain collectively through representatives of their own choosing, and to engage in other concerted activities for the purpose of collective bargaining or other mutual aid or protection, and shall also have the right to refrain from any or all of such activities .... .
}

All collective action is not "concerted activity" under § \%. See, e.g., Southern S.S. Co. v. NLRB, 316 U.S. 3I (I942); Cox, The Right To Engage in Concerted Activities, 26 IND. L.J. 3 I9 (I95r). Intermittent work stoppages are not "concerted activities" under § 7. International Union, UAW v. Wisconsin Employment Relations Bd., 336 U.S. 245 (I949) (the Briggs-Stratton case). Such conduct probably is not an unfair labor practice, however. Textile Workers v. NLRB, 227 F.2d 409 (D.C. Cir. I955), cert. dismissed, 352 U.S. 864 (I956); cf. Insurance Agents' Union v. NLRB, 260 F.2d 736 (D.C. Cir. 1958), cert. granted, 358 U.S. 944 (1959) (No. 557). If an employer is to get relief against such unprotected activity, it must come from a court. Of course, a federal court should not grant an injunction in this situation. The point is that the temptation may be there, and that the principal restraint is a judicial habit of interpreting the Norris-LaGuardia Act literally.

${ }^{48}$ Cf. Mastro Plastics Corp. v. NLRB, 350 U.S. 270, 279-84 (I956).

${ }^{49}$ See, e.g., Opera On Tour, Inc. v. Weber, 285 N.Y. 348, 34 N.E.2d 349 (I94I); Markham \& Callow, Inc. v. International Woodworkers, I70 Ore. 5I\%, I35 P.2d 727 (I943).

${ }^{50}$ See generally Frankfurter \& Greene, The Labor InJunction (1930). 
extent to which it should be used again to curb peaceful strikes is for Congress to say explicitly. And of course, Congress has done just that. It has expressly cut back Norris-LaGuardia at some points. The strike in breach of contract, however, is not one of these points. Even after Lincoln Mills it is difficult to ignore this fact, and it distinguishes $M$ ead $I$ from Chicago River $\mathcal{E}$. Indiana R.R. Since Congress did have Norris-LaGuardia in mind when it passed Taft-Hartley, there seems to be no room for the operation of a repeal by implication. ${ }^{51}$

\section{Section zor aNd the Promise To Arbitrate}

One argument which recommends acceptance of Magruder's conclusions in Mead $I$, namely, that the courts should play as small a part as possible in labor-management affairs, can perhaps be turned against the Judge when the problem shifts to the proper role for the courts in labor arbitration. But first, some background is necessary, background which again reveals Judge Magruder's capable handling of a question bound - and foreseeably so - for the Supreme Court.

In the absence of legislation, most states have declined to grant specific performance of the promise to arbitrate. ${ }^{52}$ The reason is obscure, but the fact is incontestable. The rule applies to the arbitration promise in commercial and in labor contracts. It means in effect that at common law the promise to arbitrate can be legally ignored. While damages are theoretically available, more than nominal damages are usually impossible to prove. ${ }^{53}$

This general common law was also federal law. ${ }^{54}$ In I925

${ }^{51}$ On this problem of accommodation between the Norris-LaGuardia Act and $\$$ 30I, see Cox, Current Problems in the Law of Grievance Arbitration, 30 RockY Mr. L. REv. 247, 252-56 (I958); Note, Accommodation of the Norris-LaGuardia Act to Other Federal Statutes, 72 HaRv. L. REv. 354, 364-68 (I958); Isaacson, The Implications of the Recent U.S. Supreme Court Decisions on Labor Arbitration, I3 RECoRd of N.Y.C.B.A. 67, 80-84 (I958).

In A. H. Bull S.S. Co. v. Seafarers' Union, 250 F.2d 326 (2d Cir. 1957), cert. denied, 355 U.S. 932 (r958), a post-Lincoln Mills case, the Second Circuit agreed with Judge Magruder in Mead $I$, and declined to enjoin under $\$$ 30r a strike in breach of a collective agreement.

52 Restatemient, Contracts $\S 550$ (I932); 6 Williston, Contracts $\S$ igig (rev. ed. I938).

53 Ibid.

${ }^{54}$ See Red Cross Line v. Atlantic Fruit Co., 264 U.S. rog, r20-22 (I924). 
Congress passed an arbitration act, which changed the federal rule with respect to some commercial contracts. ${ }^{55}$ But there was considerable doubt about whether the act applied to the collectivebargaining agreement; indeed, considerable doubt remains. ${ }^{56}$ Interest in this question today is slight, however, since in Lincoln Mills, the Supreme Court decided, without referring to the Arbitration Act, that section $30 \mathrm{r}$ itself empowers a federal court to order specific performance. ${ }^{57}$

Judge Magruder's pre-Lincoln Mills approach in Local $205^{58}$ was somewhat different. He performed in much the same fashion here as he had earlier in the opinion on the Norris-LaGuardia question. His is a careful and scholarly analysis of the three issues which remain after the anti-injunction statute is disposed of. The first is a source-of-law question. Does federal or state regulation control the availability of specific performance? Traditionally, the power to grant or not to grant specific performance was determined by the law of the forum. ${ }^{59}$ To the Judge there was no reason to depart here from traditional doctrine. ${ }^{60}$ Accordingly, his answer to the first question was "federal law."

The second question was whether section $30 \mathrm{r}$ itself changed the common-law arbitration rule. Judge Magruder disagreed with the position ultimately taken by the Supreme Court. He found

${ }^{55} 9$ U.S.C. $\S \S \mathrm{I}-\mathrm{r} 4$ (I952).

${ }^{58}$ See Cox, Grievance Arbitration in the Federal Courts, 67 HARv. L. Rev. 59I (1954); Cox, Current Problems in the Law of Grievance Arbitration, 30 RockX MT. L. REv. 247, 257 (I958).

${ }^{57} 353$ U.S. 448 (I957).

If an Act that authorizes the federal courts to enforce arbitration provisions in contracts generally, but specifically denies authority to decree that remedy for "contracts of employment" were available, the Court would hardly spin such power out of the empty darkness of $\$ 301$. I would make this rejection explicit, recognizing that when Congress passed legislation to enable arbitration agreements to be enforced by the federal courts, it saw fit to exclude this remedy with respect to labor contracts.

Id. at 466 (Frankfurter, J., dissenting).

${ }^{58}$ Local 205, United Elec. Workers v. General Elec. Co., 233 F.2d 85 (Ist Cir. 1956), aff'd, 353 U.S. 547 (r957).

${ }^{59}$ See, e.g., Red Cross Line v. Atlantic Fruit Co., 264 U.S. Iog (r924). See generally Gregory \& Orlikoff, The Enforcement of Labor Arbitration Agreements, I7 U. CHI. L. REv. 233 (I950).

${ }^{60}$ Bernhardt v. Polygraphic Co. of America, 350 U.S. I98 (I956), troubled the Judge somewhat. Bernhardt is a diversity case in which the Supreme Court held that state law controlled the question whether a plaintiff could obtain specific enforcement of the promise to arbitrate. Judge Magruder distinguished Bernhardt upon the ground that the basis of jurisdiction in a $\$ 301$ proceeding is the "arising under" clause of article III. 233 F.2d at 95. 
no evidence in the language of the statute or in its legislative history to support such a change. Of particular importance to the Judge was the fact that section $30 x$ did not provide "the procedural specifications needed for administration of the power to compel arbitration." ${ }^{61}$

The final question then was whether the United States Arbitration Act had changed the common-law rule, and, in conjunction with section 301 , authorized a district court to order arbitration. He found that it did after a painstaking, but engrossing, inquiry into language, history, precedent and purpose. He found that the collective-bargaining agreement was not a "contract of employment" within the exclusionary language of the statute, ${ }^{62}$ but was a contract "evidencing a transaction involving commerce." ${ }^{63}$

The Judge is persuasive on each of these points. Why the Supreme Court in Lincoln Mills ignored his analysis of the Arbitration Act - indeed, ignored the Arbitration Act itself - and rested its opinion solely on section $30 x$, leaving the lower federal courts to create their own procedural rules for arbitration, is something of a mystery. ${ }^{64}$

In Lincoln Mills and its companion cases the Supreme Court did not devote itself to any of the problems the lower federal courts were bound to face in subsequent arbitration cases under section 30r. In Magruder's circuit the cases - and there have been several ${ }^{65}$ - center around this problem: Union and employer have a collective agreement with a grievance procedure and an arbitration clause. A dispute arises. It is processed through the grievance procedure and remains unsettled. The union demands arbitration, but the employer refuses, claiming the dispute is not an issue subject to arbitration under the contract. The union goes to court under section zor to compel arbitration. (Or the

${ }^{61} 233$ F.2d at 97 .

629 U.S.C. § I (I952); see 233 F.2d at roo.

${ }^{63} 9$ U.S.C. $\$ 2$ (I952); see 233 F.2d at 98.

${ }^{64}$ See note 57 supra for Mr. Justice Frankfurter's partial explanation and Cox, Current Problems in the Law of Grievance Arbitration, 30 Rockr MT. L. Rev. 247, 257 (I958), for Professor Cox's. Neither explanation goes to why the Court declined to discuss the act.

${ }^{65}$ Local 20I, Int'l Union of Elec. Workers v. General Elec. Co., 262 F.2d 265 (Ist Cir. 1959); Local r49, Am. Fed'n of Technical Eng'rs v. General Elec. Co., 250 F.2d 922 (rst Cir. 1957), cert. denied, 356 U.S. 938 (1958); Boston Mut. Life Ins. Co. v. Insurance Agents' Union, 258 F.2d 516 (rst Cir. I958); New Bedford Defense Prod. Div. v. Local IIr3, UAW, 258 F.2d 522 (Ist Cir. I958). 
employer goes to court under section 301 and the Declaratory Judgment Act ${ }^{68}$ for a ruling that the dispute is not arbitrable.)

Lincoln Mills makes it clear that the court has jurisdiction. But a most difficult question remains, namely, what is the proper role of the district court in such a pre-arbitration contest? This much may be safely ventured: The basis for judicial intervention is the agreement between the parties. That is, the proceeding under section $30 x$ is a suit for breach of contract. Whether the Arbitration Act applies or not, in the absence of a promise to arbitrate the court may not force arbitration upon the parties. Accordingly, it might be thought that before issuing an order compelling arbitration, or an order staying arbitration, or an order staying a legal proceeding pending arbitration, the district court must determine whether the parties agreed to submit the dispute to private settlement. If they did not, present refusal by one is not a breach of contract. Perhaps it is more precise to say that the court must decide whether the arbitrator is given jurisdiction by the parties. It may be that the contract empowers the arbitrator to determine in the first instance whether the underlying dispute is arbitrable.

All of this seems easy enough, but like section $30 \mathrm{I}$ itself it is not easy at all; and there are good reasons why it is not.

To begin with, language in any negotiated document is likely to be ambiguous. And the more complicated the transaction or series of transactions which the document purports to regulate, the more inexact the language must be. A transaction may be complicated because of numerous unpredictable factors - factors which are unforeseeable or uncontrollable. When this is the case, it may be necessary, indeed it often is necessary, to avoid precision. Such purposeful ambiguity, however, may lead to seeming inconsistencies within the four corners of the document. Furthermore, if an agreement must be reached as it sometimes must, a powerful temptation is created, and often quite properly indulged, not to face the hard questions which hopefully will never arise.

The collective agreement establishes the basic working rules of a plant with perhaps thousands of employees. It may run for as many as five years. It is written for the worker in the plant. It applies to what is necessarily a dynamic, continuing relationship, one which can be incredibly complicated. A collective agreement,

${ }^{68} 28$ U.S.C. $\S \S 220 I-02$ (I952). 
moreover, is a document to which the parties must agree. There is no practical alternative.

It may be profitable here to adopt a common oversimplification and remind the lawyer who is not a labor specialist that, because of the combination of these factors, the collective-bargaining agreement is not like the commercial contract at all but rather is like a statute, or perhaps a constitution. This is an oversimplification because it drops all "commercial contracts" into a vast undifferentiated class, and suggests that the construction of such contracts is comparatively easy. Although the analogy to statute or constitution is not spoiled by this oversimplification, it should not be pressed too far; for while the courts belong in the business of constitutional and statutory interpretation, they are ill-suited to the task of construing the collective-bargaining agreement.

Unlike legislation, the collective agreement is not of general application. It is rather an intensely personal document regulating a unique situation. This is true even though there may be some uniformity in phrasing from agreement to agreement. The nature of the industry, the history of collective bargaining, the nature of the union, the composition of the bargaining unit, the attitude of the employer - to mention only factors of obvious importance impart an individualized meaning to the phrases and clauses, sections and titles of each labor contract.

Collective bargaining as a way of ordering labor-management affairs has proved successful because it is sensitive and adaptable to the requirements of diverse industries. This means that each agreement must be projected against its peculiar background if its meaning is to be discovered. This is not a job for a court. Judicial construction leads to a standardization antipathetic to the idea of collective bargaining. These characteristics of the labor agreement have not escaped attention. ${ }^{67}$ It is, it seems to me, one reason why labor arbitration is exceedingly common, and why use of a permanent umpire is often favored.

The analogy then, although it is still attenuated, is perhaps better made between the collective-bargaining agreement and a broad regulatory statute, the administration of which has been entrusted initially to an expert agency in recognition of the institutional limitations of the courts.

${ }^{87}$ See, e.g., Shulman, Reason, Contract, and Law in Labor Relations, 68 HaRv. L. Rev. 999 (1955); Summers, Judicial Review of Labor Arbitration or Alice Through the Looking Glass, 2 BufFado L. REv. I, 13-20 (1952). 
If this is the case, what can now be said about the proper role for the courts in pre-arbitration proceedings? First of all, the parties at this stage ought not to resort to the courts. And, of course, they very rarely do. ${ }^{68}$ The question of arbitrability should be submitted by the parties to the arbitrator for initial determination. He should, to pursue the administrative-law analogy, have primary jurisdiction. $^{69}$ The parties can, and should, expressly state in the arbitration clause that questions of arbitrability are, in the first instance, to be resolved in this fashion.

Second: Assuming a commitment to a policy of judicial enforcement of the promise to arbitrate, wise labor policy and a respect for the federal courts - i.e., not asking of them more than they are able to deliver - should influence a congressman to favor a statute which would narrowly confine the role of the courts in pre-arbitration proceedings. When the collective-bargaining agreement contains an arbitration provision, the statute should limit the court's inquiry to whether the demand for arbitration was raised in good faith. ${ }^{70}$

Much the most difficult question, and the one to which Judge Magruder has had to address himself, is what a federal district

${ }^{88}$ The American Arbitration Association's report of a study of I,I83 grievancearbitration cases decided in 1954 shows how sensible the parties generally are.

Judicial procedures are rarely invoked either to compel arbitration or to confirm or vacate awards. The examination of the cases revealed few instances in which recourse was made to the courts, as shown below ....

Cases with indication of court action Cases with no indication of court action Total

$\begin{array}{cc}\text { No. of Cases } & \text { Percentage } \\ \mathrm{I} 2 & 1.0 \\ \mathrm{I}, \mathrm{I} 7 \mathrm{I} & \frac{99.0}{\mathrm{I}, \mathrm{I} 83}\end{array}$

An indication of the disposition of the twelve contested cases is revealing. In three cases, court orders were issued directing that arbitration proceed. In a fourth case, a motion for an injunction staying arbitration proceedings was denied. In five other cases, awards were confirmed. Three of these cases were brought to court for routine confirmation although the employers had not refused to comply with the award or contested its validity. Awards were vacated in only three cases.

American Arbitration Ass'n, Procedural and Substantive Aspects of LaborMANAGEMENT ARbitration II-I2 (I957).

${ }^{69}$ The analogy to primary jurisdiction, however, should not be pressed too far. See note 97 infra.

${ }^{70}$ Of course, such a statute would necessarily involve the court to some extent in the reasonableness of the claimant's case. Any inquiry into "good faith" necessitates this. But, hopefully, this involvement would be very limited indeed. The scope of judicial review after an award is, of course, a discrete problem. It can quite properly be more extensive, for the court has the benefit of the arbitrator's expertness. 
court should do today in a pre-arbitration proceeding under section 30I. Were it not for the fact that the Judge's opinions suggest a different approach, the answer might seem to be simple enough. In view of what has already been said about the institutional inability of courts to deal with collective agreements, wise labor policy dictates that judges refrain from a full-dress construction of the agreement, and leave as much as possible for the arbitrator to decide.

To borrow examples from some of Magruder's cases, suppose first ${ }^{71}$ that an arbitration clause provides that "any grievance concerning the interpretation or application of this Agreement" may be submitted to arbitration. A dispute arises over vacation pay for several employees who were laid off in September, the company contending that they are not entitled to such pay. The contract provides that only employees on the "active payroll" on October $3 \mathrm{I}$ are eligible for vacation pay, and defines active payroll as "the list of employees who have qualified to receive wages from the Company and who have not been removed from the list due to discharge, quit, layoff, leave of absence, or transfer to inactive payroll." If the company declines to arbitrate this grievance and the union seeks to compel arbitration under section $30 r$, it seems clear that a judge ought to order arbitration even though it might seem to him that the company's position on the merits is inescapably right.

For a second example, ${ }^{72}$ suppose that an arbitration clause between an insurance company and a union of insurance agents provides that "no grievance shall be subject to arbitration unless it involves: (a) A dispute about the interpretation or application of any provision of this Agreement or the application of any rule or regulation of the Employer now or hereafter in force. (b) The termination, suspension, or disciplinary action against any senior [insurance] agent." The clause also contains deadlines for submitting a demand for arbitration, the naming by both parties of representatives to an arbitration board, and the selection by those representatives of an impartial chairman. It further provides that if the other party fails to designate a representative within the allotted time, the party demanding arbitration may request

\footnotetext{
${ }^{71}$ The example is based upon New Bedford Defense Prod. Div. v. Lacal III3, UAW, 258 F.2d 522 (Ist Cir. I958).

${ }^{72}$ This example is based upon Boston Mut. Life Ins. Co. v. Insurance Agents' Union, 258 F.2d 516 (Ist Cir. I958).
} 
the American Arbitration Association to name a single arbitrator to hear the dispute. The agreement, however, does not set a time limit for making a request to the A.A.A.

A senior agent is discharged in October I956. The union demands arbitration in November, but the company does not name a representative to the arbitration board. In October I957, eleven months later, the union requests the A.A.A. to designate an arbitrator, and it does. When the company declines to proceed before the arbitrator, the union seeks relief under section 301. The company insists that the union has not satisfied a condition precedent to the company's duty to arbitrate. It argues that the union had to make application to the A.A.A. within a reasonable time, and that eleven months is clearly not reasonable.

I take it that a court imbued with the wisdom which counsels restraint would here also order arbitration. The court is not a proper institution to determine whether the contract requires that the union act within a reasonable time. Furthermore, even if the contract does require action within a reasonable time, the court certainly ought not to determine whether eleven months satisfies the requirement. These are questions which quite properly should be addressed in the first instance to the arbitrator. ${ }^{73}$

A third example worth considering, also taken from a Magruder case, ${ }^{74}$ involves an agreement between a Boston newspaper and the Newspaper Guild, which in terms limits arbitration to "discharges," and which allows an arbitrator to award severance pay to a discharged employee under certain circumstances. A grievance arises concerning the transfer of a veteran employee to an undesirable shift - the so-called "lobster" shift - which the union contends constitutes a "constructive" discharge, although the employee is still working. If the newspaper declines to arbitrate on the ground that there is no discharge, and the union seeks to compel arbitration under section 3or, the court should, as a matter of sound labor policy, order arbitration. The arbitrator is best suited to make the initial determination of whether "discharge" includes transfer to the "lobster" shift in the newspaper industry in Boston.

${ }^{73}$ Cf. In the Matter of Jacobson, I6I F. Supp. 222 (D. Mass.) (Wyzanski, J.), rev'd sub nom. Boston Mut. Life Ins. Co. v. Insurance Agents' Union, 258 F.2d 5 Y6 (Ist Cir. 1958).

${ }^{74}$ This example is based upon Newspaper Guild v. Boston Herald-Traveler Corp., 238 F.2d 471 (Ist Cir. I956). 
The desirability as a matter of labor policy of judicial restraint is present in each one of these three cases, but most particularly in example three. In the first two situations, even absent restraint, there need be no overlap in the judicial proceeding between the issue of arbitrability and the merits of the underlying dispute. The dispute over vacation pay in example one is clearly the type or class of grievance made arbitrable by the agreement. Therefore, as a matter of ordinary contract law, there would be no need for a court to inquire into the merits of the dispute. It seems likely that the parties intended all unresolved disputes of this type to go to arbitration, not just disputes which a court might think were difficult to decide. In example two, the disagreement about "reasonable time" is a pure arbitrability question. However, in example three, the "lobster"-shift case, one of the questions necessarily involved in the merits - whether there has been a "discharge" - is one which a court as a matter of ordinary contract doctrine would reach at this stage absent an exercise of judicial abnegation. "Shift transfers" are not a class of disputes ordinarily arbitrable under an arbitration clause limited to "discharges."

The greater the overlap between the merits of the underlying dispute and the question of that dispute's arbitrability, the more important it usually is - as a matter of labor policy - that the enforcing court restrain itself. If it does not, it will become ever more involved in the increasingly difficult questions of meaning and custom, questions it is incompetent to decide. Typically, this happens in cases involving disputes over decisions claimed by management to be within its sole discretion, disputes, in other words, over so-called management prerogatives.

For example - and this is not a case that has been before Judge Magruder ${ }^{75}$ — suppose a collective agreement says nothing about subcontracting. It contains a union-recognition clause, a union-security clause, a work-classification clause, and a provision for arbitration of "disputes involving the interpretation and application" of the contract. During the term of the agreement, employer, a rapid-transit company, subcontracts repair work on fare boxes formerly done by its employees. The union objects, and demands arbitration. It argues that subcontracting violates the recognition, security, and work-classification clauses in the

${ }^{75}$ The example is suggested by Local 1509 , Amalgamated Ass'n of St. Elec. Employees v. Eastern Mass. St. Ry., I62 F. Supp. 942 (D. Mass. I958). 
agreement; and therefore that the employer's action creates a "dispute involving the interpretation and application of the contract." The employer contends that there is nothing in the agreement about subcontracting. It urges that the clauses cited by the union have nothing to do with the problem and that, therefore, the dispute does not involve the "interpretation and application of the contract," and is not arbitrable.

If the court, in order to reach its decision, looks beyond the arbitration clause to the other provisions cited to it, it will be dealing with issues germane to the merits of the dispute as well as to the threshold question of arbitrability. Absent an affirmative exercise of restraint, dictated by a sense of institutional incompetence, however, a court would quite properly go beyond the arbitration clause in an effort to determine the intention of the parties. Did they mean to submit this type of dispute to arbitration? Is there language in the agreement to be interpreted and applied which has anything to do with subcontracting?

This is really the factor that distinguishes this example from example one, the vacation-pay case. There, although the employer might have argued that the meaning of the vacation-pay clause is beyond dispute and accordingly that there is no genuine "dispute" to arbitrate, it seems plain that the intention of the parties was to provide for arbitration of the kind of issue raised by the union. Even a court which thought itself competent to deal with these problems would here have to go out of its way to mix the question on its merits with the question of arbitrability.

Some courts in the vacation-pay type of case apparently would go to the merits. " $[\mathrm{T}]$ he mere assertion by a party of a meaning of a provision which is clearly contrary to the plain meaning of the words cannot make an arbitrable issue," said a New York court in International Ass'n of Machinists v. Cutler-Hammer, Inc. ${ }^{76}$ It went on to explain: "It is for the Court to determine whether the contract contains a provision for arbitration of the dispute tendered, and in the exercise of that jurisdiction the Court must determine whether there is such a dispute. If the meaning of the provision of the contract sought to be arbitrated is beyond dispute, there cannot be anything to arbitrate and the contract

${ }^{76} 27 x$ App. Div. 9I7, 9I8, 67 N.Y.S.2d 3I7, 3r8, af'd, 297 N.Y. 5r9, 74 N.E.2d 464 (I947). 
cannot be said to provide for arbitration." 77 Although this has been raised to the dignity of a doctrine, it would seem to be rooted in hostility to arbitration and it has been roundly criticized. ${ }^{78}$ New York, itself, is moving away from the Cutler-Hammer doctrine. ${ }^{79}$

Judge Magruder in New Bedford Defense Prod. Div. v. Local $I I I_{3}, U A W^{80}$ - a case very similar to the vacation-pay example - declined to follow Cutler-Hammer. He quoted with approval Judge Wyzanski's opinion: "Issues do not lose their quality of arbitrability because they can be correctly decided only one way." 81 But there is ample evidence in the Judge's arbitration opinions to indicate that in the subcontracting case he would, in deciding the question of arbitrability, look deep into the merits of the underlying dispute. In short, the Judge in pre-arbitration proceedings does not view his role as limited, because of an institutional incompetence, by any notion of restraint. To the contrary, his approach in these cases is the same as it would be in any case which calls upon a judge to interpret a contract.

In the first place, Magruder has taken the position that "the issue of arbitrability under the collective bargaining agreement is inescapably an issue which the district court must determine for itself as a matter of interpretation of the terms of the arbitration article" 82 unless "an arbitration clause, either expressly or by broadly stating its scope to include disputed interpretations of any contract term ... refer[s] the very question of arbitrability to the arbitrator for decision." 83 Thus, the Judge has

\footnotetext{
${ }^{77}$ Ibid.

${ }^{78}$ See, e.g., Summers, Judicial Review of Labor Arbitration or Alice Through the Looking Glass, 2 Burfaro L. Rev. I (I952); Mayer, Judicial "Bulls" in the Delicate China Shop of Labor Arbitration, 2 LAB. L.J. 502 (I95I); Rosenfarb, The Courts and Arbitration, N.Y.U. 6th ANN. Conference on LABor I6x (1953); Cox, Current Problems in the Law of Grievance Arbitration, 30 Rocky MT. L. REv. 247 (1958). But see Marceau, Are All Interpretations "Admissible"?, I2 ARB. J. (n.s.) I50 (r957).

${ }^{79}$ See In the Matter of Bohlinger \& National Cash Register Co., 305 N.Y. 539, II4 N.E.2d 3 I (I953); Kharas \& Kroetz, Judicial Determination of the Arbitrable Issue, II ARB. J. (n.s.) I35 (I956).

${ }^{80} 258$ F.2d 522 (Ist Cir. I958).

${ }^{82} I d$. at 526.

${ }^{82}$ Local I49, Am. Fed'n of Technical Eng'rs v. General Elec. Co., 250 F.2d 922, 930 (Ist Cir. I957), cert. denied, 356 U.S. 938 (1958). This is Judge Magruder's position "whether we look to the terms of the Arbitration Act, or whether we look exclusively to the terms of $\S 301$ (a) ...." Ibid.

${ }^{83}$ Local 205, United Elec. Workers v. General Elec. Co., 233 F.2d 85, IoI (Ist Cir. I956), aff'd, 353 U.S. 547 (I957).
} 
never found that the question of arbitrability is for the arbitrator. In Boston Mut. Life Ins. Co. v. Insurance Agents' Union, example two above, he suggested that "practical considerations as to what would best promote effective labor arbitration might lead the court, in construing ambiguous language, to adopt an interpretation giving a broad scope to the arbitrator's function." 84 But he nonetheless declined to send the reasonable-time issue to the arbitrator for determination. And in Goodall-Sanford, Inc. $v$. United Textile Workers, the Judge determined arbitrability, in the face of an arbitration article providing that "any dispute which relates solely to the meaning and application of this Agreement or any individual grievance may be referred to arbitration." 85

In the second place, in deciding whether the underlying dispute is arbitrable, Judge Magruder has shown no reluctance to take hold of the issue and decide it as a court would decide any matter of contract interpretation. In Newspaper Guild v. Boston HeraldTraveler Corp. ${ }^{86}$ - the "Iobster"-shift case - the Judge decided that there was no agreement to arbitrate the underlying dispute, because the transferred newspaperman was still employed by the newspaper and could not be considered "constructively" discharged.

In Local I49, Am. Fed'n of Technical Eng'rs v. General Elec. $\mathrm{Co}^{87}$ - the Judge's most celebrated post-Lincoln Mills case ${ }^{88}$ the arbitration clause made "any grievance which involves the interpretation or application of this Agreement" arbitrable, but added that "no arbitrator shall have the authority to establish a wage rate or job classification ...." The contract further provided, in an article headed "Wage Rates," that "job classifcations, job rates and step rates are as shown on Exhibit 'B.'" Exhibit " $B$ " listed six job grades by number, showing a monthly salary for each, but contained no description of the jobs themselves. The union complained that four employees had been incorrectly graded. Magruder, in declining to compel arbitration, held that "the collective bargaining agreement contains absolutely no language by way of job descriptions which could be interpreted

\footnotetext{
${ }^{84} 258$ F.2d 5I6, 5I7 (Ist Cir. I958).

${ }^{85} 233$ F.2d I04, IO6 (Ist Cir. I956), aff'd, 353 U.S. 547 ('957).

${ }^{86} 238$ F.2d 47 I (rst Cir. 1956).

${ }^{87} 250$ F.2d 922 (Ist Cir. I957), cert. denied, 356 U.S. 938 (I958).

${ }^{88}$ See, e.g., Cox, Current Problems in the Law of Grievence Arbitration, 30 Rocky MT. L. REv. 247, 256-64 (I958); 72 HARv. L. REv. 577 (I959).
} 
or applied for the purpose of determining whether the duties performed by a particular employee fall within any particular grade." 80

Judge Magruder's approach to arbitrability is further illustrated by his most recent case, Local 2or, Int'l Union of Elec. Workers v. General Elec. Co. ${ }^{90}$ The contract provided that any grievance involving "the interpretation or application of a provision of this Agreement" was arbitrable. The question of arbitrability was by an express provision of the contract itself left for the court. Thus, the issue before Magruder was the arbitrability of the underlying dispute, namely, the transfer, after a reduction in working force, of one employee rather than another to the same job in the same plant but on a different shift. The union claimed that this transfer violated Article XI of the collective agreement, entitled "Reduction or Increase in Forces." Article XI established seniority - and the aggrieved employee was alleged to have top seniority - as the "major factor determining the employees to be laid off or transferred (exclusive of upgrading transfers to higher rated jobs)." ${ }^{91}$ The Judge concluded, after a close reading of the contract, and an examination of extrinsic evidence, that "the natural meaning of ["transfer" in Article XI] . . . particularly in the labor context, is that [it] . . a applies merely to a change of job or of physical location, not where the same job is maintained in the same plant but the shift is changed." ${ }^{22}$ Accordingly, he declined to compel arbitration, holding that there was no language in Article XI to "interpret or apply."

Why has the Judge in these pre-arbitration cases approached his task as he would approach the usual case of contract interpretation? Demonstrably, it is not because he is unaware of the "viewpoint urged in responsible quarters" 93 - a viewpoint

\footnotetext{
89250 F.2d at 930 .

${ }^{00} 262$ F.2d 265 (1st Cir. I959).

${ }^{21}$ Id. at 269 .

${ }^{22} I d$. at 27 I.

${ }^{93}$ Local I49, Am. Fed'n of Technical Eng'rs v. General Elec. Co., 250 F.2d 922, 926-27 (Ist Cir. I957), cert. denied, 356 U.S. 938 (I958):
}

We are aware of a viewpoint urged in responsible quarters that the interests of effective labor arbitration would best be served by committing to the arbitrator in the first instance the question of arbitrability, that is, the question whether there is any issue to be arbitrated under the collective bargaining agreement. It is said that a collective bargaining contract is a very special type of document, in respect of interpretation, as to which an arbitrator has certain advantages over a court; that a collective bargaining agreement, though embracing a multitude of terms covering numerous employees working at various tasks, cannot be expected to have pin-pointed each of many problems 
not dissimilar from the one developed above - as to what constitutes wise labor policy. Yet, I think part of the explanation for Magruder's approach, but only part, is that he does not wholly believe all that he has read and heard in these quarters. In his disbelief - or better, his skepticism - he stands with the vast majority of judges who have, as judges, ruminated upon the problem of the judicial role in labor arbitration. ${ }^{94}$

Magruder tells us of his skepticism:

While not ignoring the force of these considerations [namely that because of the nature of the labor contract, arbitrators and not judges should, in the first instance determine the arbitrability of the underlying dispute], it seems to us that they would be persuasive not so much in a case like the present, but rather in inducing the parties to make a voluntary submission to arbitration, and in inducing the parties to include terms in a collective bargaining agreement giving wide scope to the questions to be submitted to arbitration.

But when one of the parties needs the aid of a court, and asks the court for a decree ordering specific performance of a contract to arbitrate, we think that the court, before rendering such a decree, has the inescapable obligation to determine as a preliminary matter that the defendant has contracted to refer such issue to arbitration, and has broken this promise. ${ }^{95}$

to be dealt with in relations between the management and the union; that the contract instead contains unexpressed assumptions that many procedures and practices will continue; that under the more simplified and speedy procedures of an arbitration, more evidence with regard to these unexpressed assumptions may be available, and an arbitrator may have the additional advantage of background knowledge derived from past experiences with the parties. Therefore it may be desirable in the first instance to have an arbitrator pass on the threshold question of arbitrability, instead of running the possible risk that a court, in the guise of ruling on this preliminary question of the jurisdiction of the arbitrator, may in effect make a ruling upon the merits of the asserted grievance.

${ }^{94}$ See, e.g., Lodge I2, Int'l Ass'n of Machinists v. Cameron Iron Works, Inc., 257 F.2d 467 (5th Cir. I958) ; International Union of Operating Eng'rs v. Monsanto Chem. Co., I64 F. Supp. 406 (W.D. Ark. I958); cf. Engineers Ass'n v. Sperry Gyroscope Co., 25I F.2d I33 (2d Cir. I957), cert. denied, 356 U.S. 932 (I958). But cf. In the Matter of Jacobson, I6I F. Supp. 222 (D. Mass.), rev'd sub nom. Boston Mut. Life Ins. Co. v. Insurance Agents' Union, 258 F.2d 5 I6 (Ist Cir. 1958) ; New Bedford Defense Prod. Div. v. Local III3, UAW, I60 F. Supp. I03 (D. Mass.), aff'd, 258 F.2d 522 (Ist Cir. I958). The like-minded approach of the New York courts is examined in detail in Summers, Iudicial Review of Labor Arbitration or Alice Through the Looking Glass, 2 BuFfaLo L. REv. I (I952). Compare Standard Oil Dev. Co. Employees Union v. Esso Research \& Eng'r Co., 38 N.J. Super. 106, II8 A.2d yo (Super. Ct. I955), with Greyhound Corp. v. Amalgamated Ass'n of St. Elec. Ry. Workers, 44 Wash. 2d 808, 27x P.2d 689 (Ig54).

${ }^{95}$ Local I49, Am. Fed'n of Technical Eng'rs v. General Elec. Co., 250 F.2d 922, 927 (Ist Cir. I957), cert. denied, 356 U.S. 938 (I958). 
The Judge is saying, is he not, that it may very well be that a court is not fully competent to decide whether the parties agreed to submit a dispute to arbitration and that, therefore, as a matter of labor policy the question would be decided better by the arbitrator. But labor policy is not the only policy that a judge must consider when questions of arbitrability come before his court.

To understand Magruder better, take again the subcontracting case referred to earlier.$^{96}$ The union is asking the court to compel arbitration of a dispute over the subcontracting of repair work on fare boxes. The contract says nothing about subcontracting, and the arbitration clause provides for arbitration of disputes involving the "interpretation or application of this Agreement." The employer's position is that he never agreed to arbitrate disputes over subcontracting and that he did not agree to allow the arbitrator to decide whether he promised to arbitrate such matters. The employer does not trust the arbitrator's judgment on either of these plainly overlapping questions. That is why he is in court. Furthermore, he fears the consequences of a wrong determination by the arbitrator even if that determination eventually will be reversed by a court. The arbitrator has stature, and there may be more discontent and unrest if his opinion is overturned than there would be if he never were allowed to render an opinion.

If a judge were totally committed to the view that, because courts are ill-suited to the task of interpreting collective-bargaining agreements, the arbitrator should have first crack, he might require the employer to show express language in the contract that disputes over subcontracting are not arbitrable, or something very close to this, before he would accept the employer's position. ${ }^{97}$ Perhaps such an approach would be a proper one for a court, but it would be at a cost. No matter how gracefully such

\footnotetext{
${ }^{86}$ See pp. 1289-90 supra.

${ }^{97}$ See In the Matter of Jacobson, I6I F. Supp. 222 (D. Mass.), rev'd sub nom. Boston Mut. Life Ins. Co. v. Insurance Agents' Union, 258 F.2d $5^{16}$ (Ist Cir. I958). It is important to distinguish any notion of "primary jurisdiction" in arbitration from "primary jurisdiction" in administrative law; and the difference is the voluntary nature of arbitration. A court may interpret a statute to give an administrative agency primary jurisdiction. To find primary jurisdiction in an arbitrator a court must find that the parties themselves agreed to have an arbitrator decide in the first instance the arbitrability of the underlying dispute.
} 
a new rule of interpretation is stated, it makes of voluntary arbitration a process less voluntary than it was before. ${ }^{98}$

Judge Magruder has, of course, declined to adopt any such canon of construction. And, this is undoubtedly because in striking a balance between voluntarism - the fact that the duty to arbitrate anything, including the question of arbitrability, rests in consent - and the recognition that courts are not fully competent to interpret collective agreements, the Judge has found the latter less weighty. This is why I suggested earlier that his is a skeptical awareness of the teaching to be found in "responsible quarters."

Moreover, although the Judge has not addressed himself directly to the question of his freedom in these labor-arbitration cases, ${ }^{99}$ my best guess is that the weight he has assigned to the factor of judicial competence to deal with collective agreements is to some extent at least a consequence of what he understands to be his responsibility to Congress and the Supreme Court. If a judge in a pre-arbitration case were proceeding under a statute which explicitly required him to approach the question of arbitrability as he would other questions of contract interpretation, he surely would not be free to disregard the legislative command. To be sure, section 30r, the statute involved in all of the arbitration cases of Judge Magruder, contains no such explicit requirement. It is vague. Often it is of little guidance in the decision of a concrete case. Nevertheless, if it is anything at all, section $30 \mathrm{I}$ is the embodiment of a congressional command that federal courts must entertain suits, in the nature of contract actions, for breach of collective-bargaining agreements.

In a damage action under section 301 for breach of a promise

${ }^{88}$ Cf. Frey, The Proposed Uniform Arbitration Act Should Not Be Adopted, Io VAND. L. REv. 709, 720 (1957).

${ }^{90}$ This much he has said:

[F] ocusing our attention exclusively on the language of $\S 30 \mathrm{a}(\mathrm{a})$, it is obvious that the plaintiff, in a suit under $\S 3$ or (a), has the burden of establishing that it is bringing a suit for appropriate relief, legal or equitable, for violation of a term of a collective bargaining agreement; and that therefore the district court, before undertaking to decree specific performance of a contract for arbitration, must necessarily first determine, as a matter of law, whether the alleged refusal to arbitrate is a violation of any term in the collective bargaining agreement.

Local I49, Am. Fed'n of Technical Eng'rs v. General Elec. Co., 250 F.2d 922, 929-30 (Ist Cir. I957), cert. denied, 356 U.S. 938 (I958). And he has read \& 301 plus the Arbitration Act in the same fashion. Local 205, United Elec. Workers v. General Elec. Co., 233 F.2d 85, Ior (Ist Cir. I956), aff'd, 353 U.S. 547 (I957). 
to check-off union dues, for example, a court must work out for itself, with whatever guidance it may draw from the NLRA, ${ }^{100}$ such questions as the enforceability of the promise, its meaning, and, of course, whether it has been broken. It is to construe the collective agreement in an effort to find out what the parties intended, and then to come to a decision on the merits. The court has, without any doubt, an inescapable obligation to do this. Surely the congressional grant of jurisdiction to undertake these tasks of contract interpretation implies a congressional determination that the courts are competent to do the job.

In my opinion, Congress is wrong; and it may be that the Supreme Court had an obligation in Lincoln Mills to say so. ${ }^{101}$ Certainly this was not an obligation of any court of appeals. After Lincoln Mills the obligation of a lower federal court pulls in the other direction.

What I am saying is that Magruder may very well believe that the basic premise for judicial abnegation in labor-arbitration cases tends to be incompatible with the very statute giving the court jurisdiction in the first place, and that therefore in determining the proper role for the court in a pre-arbitration proceeding, the Judge is less prepared than he might otherwise be to assign much weight to the factor of judicial incompetence.

This notion would not help to explain Magruder's approach in the arbitration cases if, prior to section 30I, the district courts had had original federal-question jurisdiction over suits for breach of the labor contract and section $30 \mathrm{r}$ were merely an arbitration statute. ${ }^{102}$ Typically, in states in which arbitration statutes have been enacted state courts have had jurisdiction at law on breach of the labor contract. In such a situation a court could not reason that the legislature had made any general determination about judicial competence. ${ }^{103}$ But the Congress that passed Taft-Hart-

${ }^{100}$ In a given case, $\S \S 8(\mathrm{a})(3)$ and $14(\mathrm{~b}), 6$ I Stat. I40, I4I (I947), as amended, 29 U.S.C. $\$ \S 158(a)(3)$, I64(b) (I952), might have some relevance.

${ }^{101}$ See Bickel \& Wellington, Legislative Purpose and the Judicial Process: The Lincoln Mills Case, 7 I HARv. L. REv. I, 22-35 (1957).

${ }^{102}$ Prior to $\S 301$, the federal courts' jurisdiction over suits for breach of the labor contract was limited to cases involving diversity of citizenship. State law, of course, applied to all substantive questions in such cases, including the union's capacity to sue and be sued. Pullman Standard Car Mfg. Co. v. Local 2928, United Steel Workers, I52 F.2d 493 (7th Cir. 1945).

${ }^{103}$ The argument advanced in text would have force even if the United States Arbitration Act, 9 U.S.C. $\S \S I-\mathrm{I}_{4}$ (I952), were held to apply to suits under $\S 30 \mathrm{3}$. 
ley, after expressly rejecting the idea of committing supervision of the labor contract to the expertness of the NLRB by making its breach an unfair labor practice, ${ }^{104}$ gave a general grant of jurisdiction, where it had not existed before, to the federal courts. Thus, Congress handed to the courts the task of interpreting and construing such contracts. This is what section 301 means. ${ }^{105}$

Take once more the subcontracting case: Assume this time a union sues an employer for damages under section 3or, alleging that the subcontracting of repair work on fare boxes constituted a breach of the recognition, security, and work-classification clauses of the collective-bargaining agreement. A federal district court has jurisdiction over this contest. Magruder would probably reason - if I am right about the "why" of his approach - that if a court is competent under section $30 I$ to interpret these clauses and render judgment on the merits when the case is before it in this posture, it surely must be competent to deal with these same clauses in the same way when they come before it under the same

The Arbitration Act was passed in I925. It did not have application, prior to $\S 301$, to collective-bargaining agreements because it did not - indeed, does not - apply in diversity cases. Bernhardt v. Polygraphic Co. of America, 350 U.S. I98 (r956). The judicial role in labor arbitration, if the Arbitration Act has applicability, therefore must be determined in light of Congress' general belief in the suitability of courts to interpret collective-bargaining agreements - a belief manifested in $\S 301$. For this reason, Magruder's approach to the arbitrability question should not have been affected by Lincoln Mills. And, of course, it has not been. See Local I49, Am. Fed'n of Technical Eng'rs v. General Elec. Co., 250 F.2d 922, 92930 (Ist Cir. I957).

${ }^{104}$ See Conf. Rep. No. 510, 8oth Cong., Ist Sess. 42 (I947):

Once the parties have made a collective bargaining contract the enforcement of that contract should be left to the usual processes of the law and not to the National Labor Relations Board.

${ }^{105}$ [W] hen in the House the debate narrowed to the question whether $\S 30 \mathrm{I}$ was more than jurisdictional, it became abundantly clear that the purpose of the section was to provide the necessary legal remedies. Section 302 of the House bill, the substantive equivalent of the present $\S 30 \mathrm{r}$, was being described by Mr. Hartley, the sponsor of the bill in the House:

"Mr. Barden, Mr. Chairman, I take this time for the purpose of asking the Chairman a question, and in asking the question I want it understood that it is intended to make a part of the record that may hereafter be referred to as history of the legislation.

"It is my understanding that section 302, the section dealing with equal responsibility under collective bargaining contracts in strike actions and proceedings in district courts contemplates not only the ordinary law suit for damages but also such other remedial proceedings, both legal and equitable, as might be appropriate in the circumstances; in other words, proceedings could, for example, be brought by the employers, the labor organizations, or interested individual employees under the Declaratory Judgments Act in order to secure declarations from the Court of legal rights under the contract.

"Mr. Hartley. The interpretation the gentleman has just given of that section is absolutely correct!" 93 Cong. Rec. $3656-3657$.

Textile Workers v. Lincoln Mills, 353 U.S. 448, 455-56 (I957). (Footnote omitted.) 
statute in a pre-arbitration proceeding. In the absence of anything in the contract about subcontracting, the meaning of these clauses would be plainly relevant to the determination of whether the parties intended to submit a dispute over subcontracting to arbitration.

Labor specialists, and to some extent the Judge himself, may think that a court is ill-suited to the task of solving the problem. But, if I am right, the Magruder position, at least in part, seems to be that Congress in section $30 \mathrm{I}$ has taken a different view.

At this point one thing should be made perfectly clear. These last several paragraphs are in appreciation and attempted explanation of Judge Magruder's approach in his arbitration cases. They are not necessarily an explanation or an appreciation of his holding in any particular case. They do not explain the holding in Local 20I, the seniority transfer case, for example. ${ }^{106} I$ think that there the Judge, using his own approach, was wrong with respect to the question of the arbitrability of the underlying dispute. As a matter of ordinary contract interpretation, it seems to me that the grievance was of a type or class that the parties had intended to submit to arbitration. The transfer to another shift, a question of "shift preference," probably was not a "transfer" within Article XI. The Judge, however, had no cause to reach that question for the same reason that in New Bedford he did not have to reach the question whether the employees were entitled to vacation pay. Indeed, Local 2or is too close to Cutler-Hammer for comfort.

The fact that Judge Magruder may have reached the wrong result in one or two of these cases is not very important in an assessment of the Judge. But it may be important in an assessment of section 301 . It suggests that even the best judges should not be in the business of construing collective-bargaining agreements. A look at the product of all judges in labor-contract cases since Lincoln Mills suggests that Harry Shulman was correct, as might have been expected, in urging that "the law stay out ...." 107

Realistically, of course, the courts probably are now in the business of labor-contract litigation to stay. But while Congress

${ }^{108}$ Local 20I, Int'I Union of Elec. Workers, v. General Elec. Co., 2 LAB. REL. REP. (43 L.R.R.M.) 2357 (Ist Cir. Jan. 9, 1959).

${ }^{107}$ Shulman, Reason, Contract, and Law in Labor Relations, 68 HaRv. I. REv. 999, 1024 (I955). 
is not likely to repeal section $30 \mathrm{r}$, it might be politically possible for it to write an arbitration statute which directs the courts to approach arbitrability questions with much more restraint than other contract questions. Absent such a statute, it can only be hoped that the parties will resist raising the question of arbitrability in the courts prior to its determination in the arbitration proceeding.

Section 30r, with its implication of congressional belief in judicial competence, makes it difficult for any federal court to fashion arbitration rules premised upon the assumption that the courts as institutions are ill-suited to the task of interpretation and construction of the collective-bargaining agreement. ${ }^{108}$ And, if I have been right, it would have required of the Judge something very close to a disregard of means, and a single-minded concern with result, before he could have approached his task from what many a labor specialist believes to be the sound labor-policy position. If there is one responsibility the Court of Appeals for the First Circuit owes to the Supreme Court, and to the Congress a responsibility which it has for the past twenty years consistently discharged - it is to continue, after the Judge's retirement in June, to keep any such disrespect for process far from Boston's harbor, and from the old chambers of Chief Judge Calvert Magruder.

${ }^{108}$ And indeed, the federal courts have generally approached arbitrability in a fashion similar to that of Judge Magruder. See cases cited note 94 supra. 